Walker, C. 1983. Taxonomic concepts in the Endogonaceae; spore wall characteristics in species descriptions. Mycotaxon 18: 443-455.

, and F. E. Sanders. 1986. Taxonomic concepts in the Endogonaceae. III. The separation of the genus Gigaspora Gerd. \& Trappe into two gen- era, Gigaspora and Scutellospora. Mycotaxon 27: 169-182.

Woodhouse, W. W., E. D. Seneca, and A. W. Cooper. 1968. Use of sea oats for dune stabilization in the southeast. Shore Beach 36: 15-21.

Mycologia, 79(6), 1987, pp. 905-906.

(C) 1987, by The New York Botanical Garden, Bronx, NY 10458

\title{
A POSSIBLE ENDOGONACEOUS FUNGUS FROM THE TRIASSIC OF ANTARCTICA
}

\section{SARA P. STUBBLEFTELD, THOMAS N. TAYLOR, AND ROLAND L. SEYMOUR}

\author{
Department of Botany, The Ohio State University,
} Columbus, Ohio 43210

A possible endogonaceous fungus has recently been discovered in a silicified matrix from the Triassic of Antarctica. Material was collected from the Fremouw Peak Formation near Fremouw Peak in the Beardmore Glacier region of Antarctica in conjunction with the Byrd Polar Research Center at The Ohio State University. The matrix is early-middle Triassic (Collinson et al., 1980). Specimens bear collection numbers 17,442-17,451 in The Ohio State University Paleobotany Collection.

The fungus is represented by a single specimen (FIGS. 1, 2) that consists of a nonseptate thallus with approximately thirty terminal, radiating chlamydospores. At its widest point the specimen is $0.35 \mathrm{~mm}$ diam. Chlamydospores are obovate-subspherical (54-57 x 40-54/xm) or elongate $\left(30 \times 70^{\wedge} \mathrm{ni}\right)$, and lack any internal contents. Although chlamydospore walls are thicker than hyphal walls, there is no evidence that they are laminate. Stalks are 3.5-6.5 $\wedge^{\wedge}$ wide and unbranched. All areas of the fungus show a distinctive surface pattern that is most prominent on the chlamydospores (FIG. 2). Because this pattern is similar to that on the surfaces of associated pollen grains and on the walls of plant cells, it is assumed to be an artifact of degradation. The fungus lies free in the matrix, but is closely associated with decaying plant debris, particularly bisaccate pollen grains, stems, and roots.

Although this fungus is well-preserved, it is incompletely known and its affinities are obscure. Several mycologists have noted similari- ties between the fossil and the extant endogonaceous species, Sclerocystis rubiformis Gerdemann and Trappe (1974) (Reynolds, pers. comm.; Barr, pers. comm.; Trappe, pers. comm.). Sclerocystis Berk, and Broome was established for a fungus having elongate chlamydospores arranged in a single layer and radiating from a central plexus of hyphae (Gerdemann and Trappe, 1974). Sclerocystis rubiformis differs from other species of the genus in that it includes those specimens that lack a peridium. Like $S$. rubifor$m i s$, the Antarctic fungus has terminal, generally ovoid, radiating chlamydospores and lacks a peridium. The fossil specimen, however, is considerably less compact than extant $S$. rubiformis (see Gerdemann and Trappe, 1974, Fig. 23), although sporocarps of $S$. rubiformis open somewhat as they age (Trappe, pers. comm.). The fossil also differs in producing relatively thin-walled, nonlaminated chlamydospores that are smaller than those typical of $S$. rubiformis (Trappe, pers. comm.). Furthermore, the central plexus of hyphae characteristic of the genus Sclerocystis is apparently very poorly developed in the fossil (FIG. 1). It may be that these variations in morphology reflect developmental differences. On the other hand, it is also possible that with its looser organization, smaller, non-laminated chlamydospores, and simple central region, the fossil may be a distinct organism different from any endogonaceous taxon known today.

Permineralized representatives of the Endogonaceae are known from the Devonian through- 


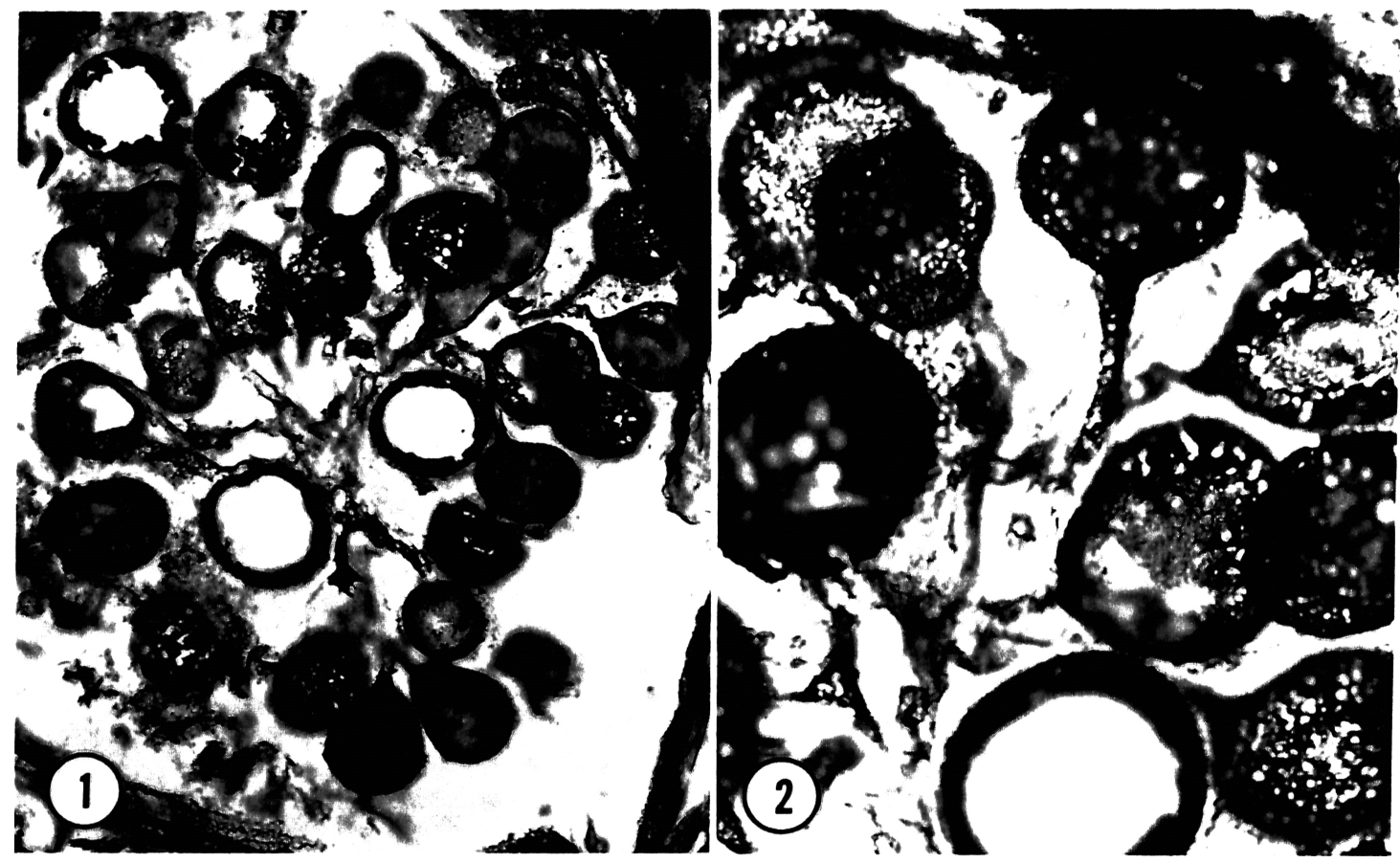

FIGS. 1, 2. Sclerocystis-like fungus. 1. Loosely arranged sporocarp with nonseptate hyphae and multiple terminal chlamydospores. 10,023A \#20, X230. 2. Higher magnification of FIG. 1 showing chlamydospores and attached hyphae. 10,023A \#20, X535.

out the Triassic (Wagner and Taylor, 1982; Stubblefield and Banks, 1983; Stubblefield et al, 1985; Stubblefield, Taylor, and Trappe, 1987). To date, all previously described Paleozoic and Mesozoic endogonaceous fungi resemble Glomus. Unlike that material, however, the present fossil is more Sclerocystis-like in organization. If further findings confirm its endogonaceous nature, this specimen will be the first reported non-G/oraws-like representative of the group from Paleozoic or Mesozoic sediments.

\section{ACKNOWLEDGMENTS}

The authors wish to thank Dr. Don Reynolds, Natural History Museum, Los Angeles, California and Dr. Donald Barr, Biosystematics Research Institute, Ottawa, Canada who first compared the fungus to Sclerocystis. We also gratefully acknowledge the assistance of Dr. James M. Trappe, Pacific Northwest Forest and Range Experiment Station, University of Oregon, Corvallis, Oregon for his evaluation of the material and much useful discussion. This project was supported in part by NSF grant BSR-8516323.
Contribution no. 600 from the Byrd Polar Research Center.

Key Words: Antarctica, Endogonaceae, fossil fungus, Sclerocystis, Triassic.

\section{LITERATURE CITED}

Collinson, J. W., K. L. Stanley, and C. L. Vavra. 1980. Triassic fluvial depositional systems in the Fremouw Formation, Cumulus Hills, Antarctica. Pp. 141-148. In: Gondwanafive. Eds., M. M. Creswell and P. Vella. A. A. Balkema, Rotterdam.

Gerdemann, J. W., and J. M. Trappe. 1974. The Endogonaceae in the Pacific Northwest. Mycologia Memoir No. 5.

Stubblefield, S. P., and H. P. Banks. 1983. Fungal remains in the Devonian trimerophyte Psilophyton dawsonii. Amer. J. Bot. 70: 1258-1261.

, T. N. Taylor, and C. E. Miller. 1985. Studies of Paleozoic fungi IV: wall ultrastructure of fossil endogonaceous chlamydospores. Mycologia 77: $83-96$.

, and J. M. Trappe. Fossil mycorrhizae: a case for symbiosis. Science 237: 59-60.

Wagner, C. W., and T. N. Taylor. 1982. Fungal chlamydospores from the Pennsylvanian of North America. Rev. Palaeobot. Palynol. 37: 317-328. 